\title{
AKTIVITAS ANTIBAKTERI EKSTRAK KULIT PISANG AMBON (MUSA ACUMINATA COLLA) TERHADAP STAPHYLOCOCCUS AUREUS SECARA IN-VITRO
}

\author{
Fajrina, Rika Fitriani Nur¹; Rahayu, Ira Gustira1; Wahyuni, Yeni1; Rahmat, \\ Mamat ${ }^{1}$ \\ 1 Jurusan Teknologi Laboratorium Medik Poltekkes Kemenkes Bandung \\ e-mail: rikafitrianinf@gmail.com uppm@poltekkesbandung.ac.id
}

\begin{abstract}
ABSTRAK
Pisang mengandung antioksidan yang tinggi. Selain itu, kulit pisang juga memiliki kandungan kimia seperti alkaloid, flavonoid, saponin, fenol, juga terpenoid yang mampu menghambat pertumbuhan bakteri. Penelitian ini bertujuan untuk mengetahui aktivitas antibakteri kulit pisang ambon, mengetahui variasi konsentrasi dari rentang $0 \%$; $0,2 \%$; $0,4 \% ; 0,6 \% ; 0,8 \%$; dan $1 \%$, juga mengetahui waktu kontak (waktu inkubasi) yang paling efektif. Waktu yang dipakai disesuaikan dengan kurva pertumbuhan bakteri yaitu 0 jam, 5 jam, 15 jam, 30 jam, dan 45 jam dengan 3 kali pengulangan sehingga terdapat 75 unit eksperimen termasuk kontrol positif dan negatif. Jenis penelitian yang digunakan adalah quasi eksperimen. Metode yang digunakan adalah makrodilusi dengan pembuatan seri pengenceran pada tabung reaksi yang berisi media cair Mueller Hinton Broth (MHB) sebagai media yang dapat menumbuhkan bakteri Staphylococcus aureus dan sejumlah tertentu suspensi Staphylococcus aureus. Seri tabung diinkubasi pada suhu $37^{\circ} \mathrm{C}$ selama waktu tertentu dan diukur absorbannya menggunakan spektrofotometer UV-Vis pada panjang gelombang $620 \mathrm{~nm}$. Ekstrak kulit pisang ambon dapat menghambat pertumbuhan bakteri Staphylococcus aureus pada konsentrasi 0,4\% dengan waktu kontak 30 jam.
\end{abstract}

Kata Kunci: Ekstrak kulit pisang ambon, Staphylococcus aureus, Kadar Hambat Minimum (KHM)

\begin{abstract}
Bananas also have high antioxidant content. In addition, banana peels also contain chemicals such as alkaloids, flavonoids, saponins, phenols, and terpenoids which can inhibit bacterial growth. The aim of this study was to determine the antibacterial activity of Ambon banana peel, to determine the concentration variation from a range of $0 \%$; $0.2 \%$; $0.4 \% ; 0.6 \%$; $0.8 \%$; and $1 \%$, also knowing the most effective contact time (incubation time). The time used was adjusted to the bacterial growth curve, namely 0 hours, 5 hours, 15 hours, 30 hours, and 45 hours with 3 repetitions so that there were 75 experimental units including positive and negative controls. The type of research used is quasi-experimental. The method used is macrodilution by making a series of dilutions in the test tube containing Mueller Hinton Broth (MHB) liquid media as a medium that can grow Staphylococcus aureus bacteria and a certain amount of Staphylococcus aureus suspension. The tube series was incubated at $37^{\circ} \mathrm{C}$ for a certain time and the absorbance was measured using a UV-Vis spectrophotometer at a wavelength of 620 $\mathrm{nm}$. Ambon banana peel extract can inhibit the growth of Staphylococcus aureus bacteria at a concentration of $0.4 \%$ with a contact time of 30 hours.
\end{abstract}

Keywords: Ambon banana peel extract, Staphylococcus aureus, Minimum Inhibitory Concentration (MIC). 


\section{PENDAHULUAN}

Pisang bisa dikatakan sebagai buah kehidupan dan sudah dikonsumsi sejak zaman dahulu. Bahkan pisang juga dapat bermanfaat sebagai pengganti makanan pokok. Indonesia juga menjadi salah satu penghasil pisang terbesar karena sekitar 50 persen produksi pisang di Asia berasal dari Indonesia dengan lebih dari 230 jenis pisang, salah satunya pisang ambon, dan kelompok pisang yang enak setelah diolah salah satunya adalah pisang kepok. ${ }^{1,2}$ Buah yang satu ini memang terkenal multi guna, karena buah pisang bisa digunakan sebagai bahan dasar atau pendamping berbagai jenis makanan. ${ }^{3}$ Berdasarkan kandungan yang dimiliki, terdapat senyawa yang mampu menghambat pertumbuhan bakteri, salah satunya yaitu flavonoid dan tannin. ${ }^{4}$

Bakteri merupakan mikroba uniseluler dengan ukuran yang sangat kecil sehingga hanya dapat dilihat menggunakan mikroskop pada perbesaram tertentu. Bakteri tersebar luas di alam, di dalam tanah, air, makanan, hewan, manusia dan tanaman. Jumlah bakteri tergantung dalam keadaan sekitar. ${ }^{5}$ Staphylococcus aureus termasuk jenis kuman yang daya tahan hidupnya paling kuat, bahkan pada media agar miring dapat hidup selama berbulan-bulan baik dalam lemari es maupun pada suhu kamar. ${ }^{6}$ Bakteri ini mudah tumbuh pada kebanyakan media perbenihan bakteri dengan suhu optimum $37^{\circ} \mathrm{C}$ dan membentuk pigmen baik pada suhu 20$25^{\circ} \mathrm{C}$. Staphylococcus adalah salah satu penyebab penting penyakit pada manusia karena dalam keadaan normal, bakteri ini terdapat di saluran pernapasan atas, kulit, saluran cerna, dan juga ada pada vagina. Bakteri ini dapat ditularkan sendiri ketika bersin, tersebar melalui droplet, atau dapat juga melalui tangan yang terkontaminasi. Staphylococcus bersifat pathogen yang dapat menginfeksi kulit maupun luka terbuka seperti ulkus, luka bakar, atau luka bekas operasi yang memperbesar kemungkinan terinfeksi dan berakibat munculnya infeksi sistemik. ${ }^{7}$

Mikrodilusi dan makrodilusi cair merupakan salah satu metode untuk menentukan kepekaan antimikroba yang paling utama. Prosedur ini dibuat dengan konsestrasi menurun dari antimikroba dalam media cair yang diinokulasikan bakteri uji dengan minimum yaitu $2 \mathrm{~mL}$ untuk makrodilusi atau dengan volume yang lebih rendah dengan menggunakan microplate 96well. $^{8}$ Mikrodilusi tidak membutuhkan waktu yang lama karena pengujian dilakukan dalam waktu satu kali pada satu microplate dengan jumlah sumur yang banyak. Metode mikrodilusi ini dapat digunakan untuk berbagai macam mikroorganisme, murah, dan menghasilkan hasil dapat diulang. Mikrodilusi ini menggunakan sampel yang diencerkan secara berseri. ${ }^{9}$

Antibakteri adalah bahan yang dapat menghambat maupun membunuh aktivitas suatu mikroorganisme. Senyawa antibakteri ini terdiri berdasarkan mekanisme daya kerja hingga tujuan penggunaan. ${ }^{10}$ Mekanisme kerja antibakteri yaitu dengan merusak dinding sel, penghambatan sintesis protein sehingga mengganggu proses translasi dan transkripsi, rusaknya membrane plasma yang akan mengakibatkan terhambatnya pertumbuhan sel atau matinya sel, adanya penghambatan sintesis asam nukleat, dan menghambat aktivitas enzim. ${ }^{7,10}$

\section{METODE}

Jenis penelitian yang digunakan adalah Quasi Eksperimen (eksperimen semu). Pada penelitian ini, ekstrak kulit pisang dengan konsentrasi $0,2 \% ; 0,4 \%$; $0,6 \%$; $0,8 \%$; dan $1 \%$ ditambahkan ke dalam $\mathrm{NaCl}$ dengan cara mencampurnya berdasarkan berat per berat, kemudian campuran tersebut disimpan selama 0 jam, 5 jam, 15 jam, 30 jam, dan 45 jam lalu amati pertumbuhan bakteri (kekeruhan) pada 
setiap perlakuan menggunakan spektrofotometer. Data hasil pengamatan dibandingkan dengan kontrol (tanpa penambahan ekstrak). Desain penelitian yang digunakan adalah Statistic Group Comparison (perbandingan kelompok statistik).

Sampel yang digunakan adalah kulit pisang yang dikeringkan (dianginkan) dan dibuat maserat sehingga didapatkan ekstrak kulit pisang. Sampel uji kemudian dilarutkan untuk dibuat variasi konsentrasi $0,2 \%$; $0,4 \% ; 0,6 \% ; 0,8 \%$; dan $1 \%$ dengan waktu kontak 0 jam, 5 jam, 15 jam, 30 jam, dan 45 jam. Jumlah unit

\section{HASIL DAN PEMBAHASAN}

Data yang diperoleh dari penelitian dilakukan analisa statistik untuk mengetahui aktivitas antibakteri ekstrak kering kulit pisang ambon terhadap Staphylococcus aureus. Data yang dipakai adalah data absorban dari hasil eksperimen, adalah 5 perlakuan $\times 5$ waktu penyimpanan $\times 3$ pengulangan $=$ 75 unit. Pengamatan dilakukan terhadap hasil kekeruhan yang terbentuk setelah penyimpanan. Penambahan ekstrak kulit pisang ambon dilakukan menggunakan mikropipet ke dalam media MHB yang telah ditambahkan suspensi bakteri Staphylococcus aureus. Inkubasi campuran tersebut dengan variasi waktu yaitu $0,5,15,30$, dan 40 jam. Pembacaan nilai absorban dilakukan dengan menggunakan spektrofotometer uv-vis dengan panjang gelombang maksimum 620nm.

pengukuran ekstrak kering kulit pisang terhadap kontrol positif $(+)$, sedangkan kontrol negatif (-) dan blanko tidak dipakai karena hasil yang didapat negatif.

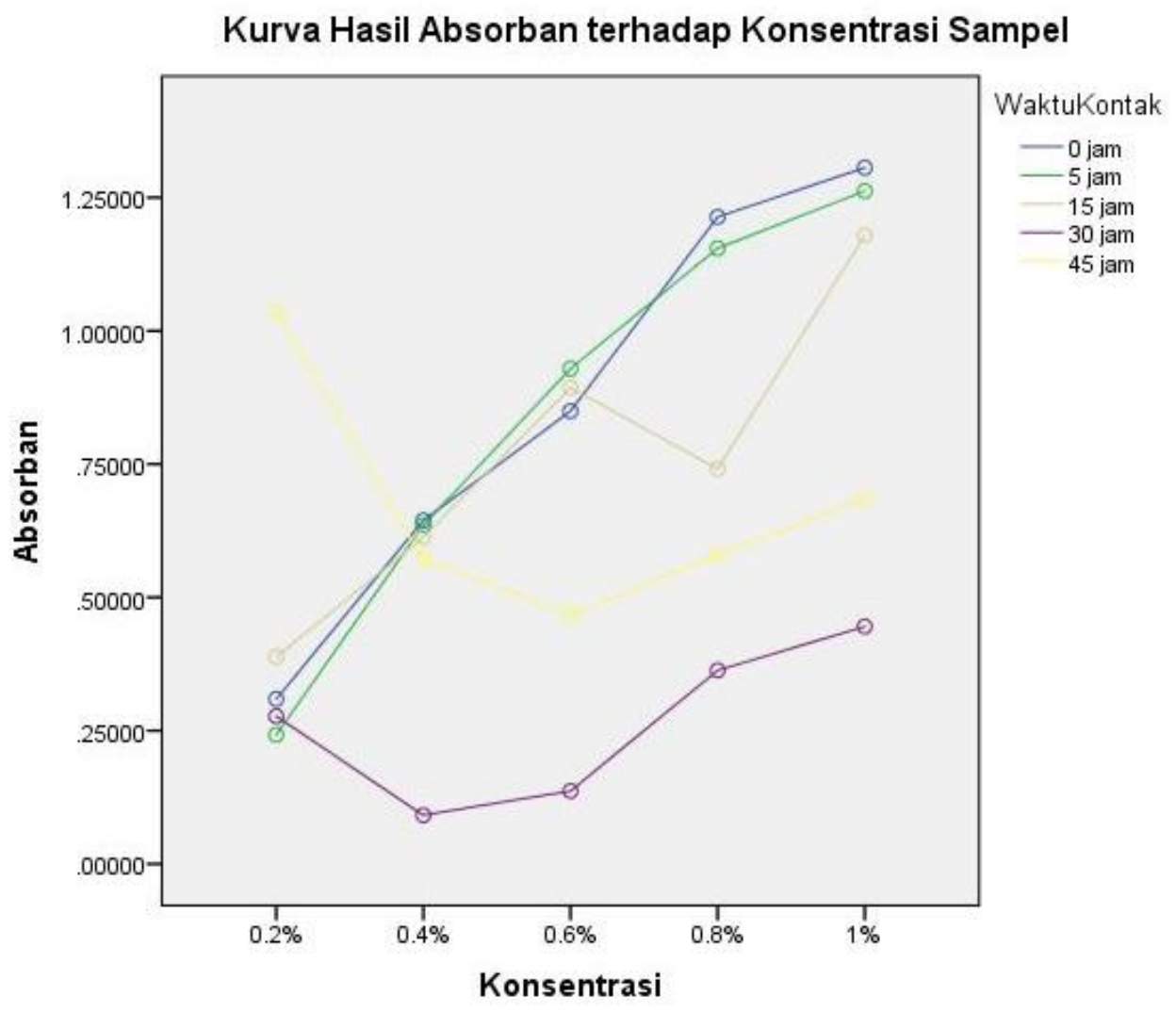

Gambar 1. Kurva Hasil Absorban terhadap Konsentrasi 
Pada kurva tersebut dapat dilihat bahwa mulai terjadi penurunan absorban pada $\mathrm{T}_{3}$ (waktu kontak 30 jam) dengan titik terendah berada pada konsentrasi ekstrak 0,4\%. Jika dibandingkan, kurva waktu kontak $\mathrm{T}_{3}$ berada di bawah kurva waktu kontak $T_{0}$. Kurva waktu kontak $\mathrm{T}_{4}$ juga mengalami penurunan nilai absorban. Jika dilihat dari nilai absorban yang didapat dari seluruh konsentrasi dan waktu kontak, keduanya berada di bawah nilai absorban $\mathrm{T}_{0}$. Hal ini menjelaskan bahwa KHM dari ekstrak kulit pisang ambon terhadap Staphylococcus aureus berada pada konsentrasi $0,4 \%$.

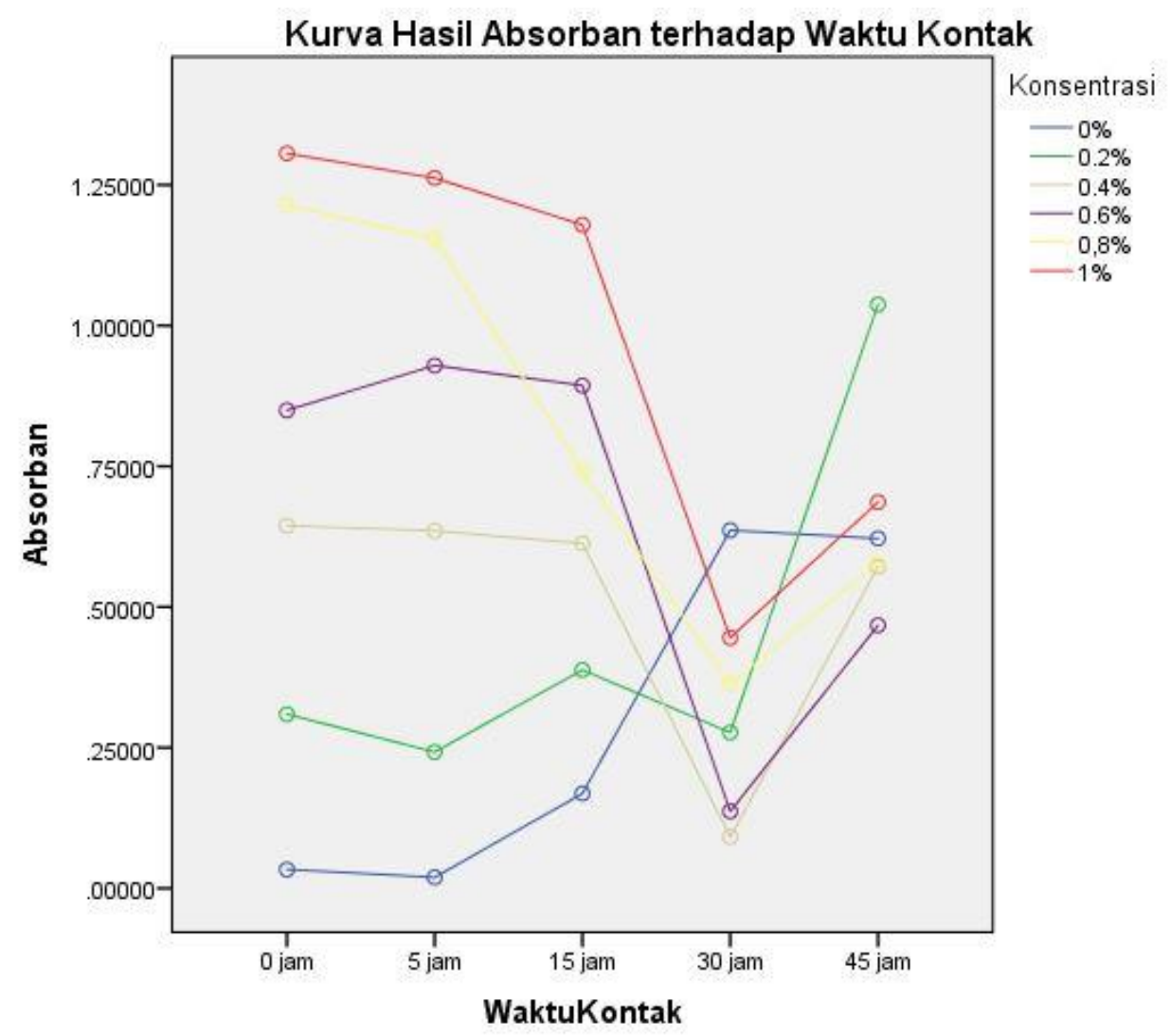

Gambar 2. Kurva Hasil Absorban terhadap Waktu Kontak

Pada kurva terlihat bahwa tidak adanya peningkatan absorban dari $\mathrm{T}_{0} \mathrm{ke}$ $\mathrm{T}_{1}$ kecuali pada konsentrasi $0,6 \%$. Keadaan pada 0-5 jam tersebut merupakan fase lag atau fase adaptasi, dimana bakteri sangat bergantung pada kondisi pertumbuhan. Kemudian masuk ke fase log atau fase eksponensial, fase ini berlangsung sekitar 5-15 jam dimana terjadi peningkatan absorban pada beberapa konsentrasi, hal ini terjadi karena pada fase ini bakteri sedang berkembangbiak. Tidak terjadinya peningkatan absorban dapat dikarenakan mulai berpindahnya fase pertumbuhan bakteri dari fase log ke fase stasioner. Adanya penurunan nilai absorban pada $\mathrm{T}_{2}$ (waktu kontak 15 jam) disebabkan karena pada masa tersebut masuk ke dalam fase stasioner dimana bakteri mengalami pertumbuhan sel secara terbatas. Fase stasioner ini berlangsung sekitar 15-30 jam pertumbuhan bakteri. Dapat dilihat bahwa pada $\mathrm{T}_{3}$ dengan waktu kontak 30 jam terjadi penurunan nilai absorban pada seluruh variasi konsentrasi. Ini menunjukkan bahwa aktivitas ekstrak kulit pisang ambon yang ditambahkan pada suspensi bakteri tersebut mempengaruhi pertumbuhan bakteri Staphylococcus aureus. Padahal seharusnya pada waktu kontak 30 jam tersebut masih berada pada fase 
stasioner, bukan fase kematian. Namun, nilai absorban kembali naik pada $\mathrm{T}_{4}$ (waktu kontak 45 jam) yang terjadi pada seluruh variasi konsentrasi. Hal ini menjelaskan bahwa ekstrak kulit pisang ambon bersifat sebagai bakteriostatik dan bukan bakterisida terhadap pertumbuhan bakteri Staphylococcus aureus. Bakteriostatik hanya menghambat pertumbuhan bakteri dengan cara mempengaruhi sintesa protein yang bekerja, yaitu menghambat perlekatan tRNA dan mRNA ke ribosom, sehingga mengganggu proses translasi dan transkripsi. Jika aktivitas antibakteri ekstrak kulit pisang ambon berkurang, bakteri kembali menduplikasi diri karena masih berada dalam fase stasioner.

Pada gambar 4.2 tersebut absorban dibandingkan dengan hasil pengukuran absorban kontrol negatif (konsentrasi $0 \%$ tanpa penambahan ekstrak) sehingga dapat dilihat kurva pertumbuhan bakteri Staphylococcus aureus pada media MHB. Pada tabel 4.8 dapat dilihat bahwa rata-rata konsentrasi ekstrak 0,4\% dengan konsentrasi ekstrak 0,6\% tidak memiliki perbedaan yang signifikan. Nilai absorban pada konsentrasi $0,2 \%, 0,4 \%$, $0,6 \%, 0,8 \%$, dan $1 \%$ juga berada di bawah nilai absorban konsentrasi $0 \%$ pada kontak waktu 30 jam. Kemungkinan yang terjadi adalah jumlah konsentrasi ekstrak kulit pisang yang ditambahkan terlalu rendah untuk dapat menghambat pertumbuhan bakteri Staphylococcus aureus pada waktu kontak 30 jam.

Adanya kekurangan pada metoda yang digunakan dapat menghambat beberapa hal. Pertama, ekstrak kering yang dilarutkan menggunakan pelarut etanol $96 \%$ tidak jernih dan terdapat endapan, hal tersebut dapat diminimalisir dengan menggunakan pelarut DMSO. Kedua, karena hasil pengenceran ekstrak tidak jernih, pembacaan menggunakan spektrofotometer pun dapat terganggu karena spektrofotometer menggunakan prinsip sinar yang mengukur warna, hal tersebut dapat diminimalisir dengan menggunakan pengukuran oleh turbidimeter. Ketiga, adanya penambahan ekstrak membuat kurva pertumbuhan bakteri bergeser, artinya pertumbuhan bakteri lebih lama. Sehingga hasil inkubasi belum dapat diukur atau diamati pada waktu pertumbuhan yang sesuai dengan waktu pertumbuhan bakteri yaitu 24 jam namun baru dapat dilihat pada waktu inkubasi 30 jam. Pada penelitian tersebut perlu dilakukan konfirmasi terhadap pertumbuhan Staphylococcus aureus menggunakan media agar dengan perhitungan angka lempeng total (ALT), sehingga dapat ditentukan lebih detail apakah penambahan ekstrak kulit pisang ambon pada media menghambat pertumbuhan bakteri Staphylococcus aureus atau tidak.

\section{SIMPULAN}

Berdasarkan hasil penelitian yang telah dilakukan, terdapat aktivitas antibakteri ekstrak kulit pisang ambon (Musa acuminata Colla) terhadap pertumbuhan bakteri Staphylococcus aureus dengan konsentrasi minimum $0,4 \%$ dan waktu kontak efektif pada inkubasi 30 jam.

Perlu dilakukan penelitian lebih lanjut untuk mengetahui aktivitas antibakteri ekstrak kulit pisang ambon (Musa acuminata Colla) terhadap pertumbuhan bakteri Staphylococcus aureus dengan metode yang lainnya, aktivitas antibakteri ekstrak kulit pisang ambon (Musa acuminata Colla) terhadap pertumbuhan bakteri dengan sifat Gram negatif, juga perlu dilakukan penelitian lanjutan dengan melakukan penanaman pada media agar untuk memastikan ekstrak memiliki daya hambat terhadap Staphylococcus aureus. 


\section{DAFTAR RUJUKAN}

1. Afandy, M. (2013, Desember 23). Manfaat Buah, Kulit, Batang, Hati, Akar, Daun, dan Bonggol Pisang Untuk Kesehatan Serta Cara Penggunaannya. Diambil kembali dari munsypedia.com: https://www.munsypedia.com/2013/12/ manfaat-buah-kulit-batang-hatiakar.html

2. Astawan, M., \& A. L, K. (2008). Khaiat Warna-Warni Makanan. Gramedia Pustaka Utama, 28-30.

3. Luthfie. (2018, 5 13). Pisang - Manfaat, Jenis, dan Informasi Penting Lainnya. Diambil kembali dari RAMESIA: https://ramesia.com

4. Atun, S., Arianingrum, R., Handayani, S., Rudyansah, \& Garson, M. (2007). Identifikasi dan Uji Aktivitas Antioksidan Senyawa Kimia dari Ekstrak Metanol Kulit Buah Pisang (Musa paradisiaca Linn.). Indo J. Chem, 83-87..

5. Dwidjoseputro. (1987). Dasar-Dasar Mikrobiologi. Djambatan.

6. Syahrurachman, A., Chatim, A., W. K, A. S., Karuniawati, A., Santoso, A., Harun, B. H., . . Warsa, U. C. (1994). Buku Ajar Mikrobiologi Kedokteran. Jakarta: Binarupa Aksara.

7. Jawetz, Melnick, Adelberg's, Brooks, G. F., Butel, J. S., \& Morse, S. A. (2001). MEDICAL MICROBIOLOGY. McGrawHill Companies Inc.

8. Balouiri, M. (2016). Methods for In-vitro Evaluating Antimicrobial Activity. Journal of Pharmaceutical Analysis, 7179.

9. Baris, O., Gulluce, M., Sahin, F., Ozer, H., Kilic, H., Ozkan, H., . . Ozbek, T. (2006). Biological Activities Of the Essential Oil and Methanol Extract Of Achillea Biebersteinii Afan. (Asteraceae). Turk. J. Biol, 65-73.

10. Luthfi, A. (2004). Kimia Lingkungan. Jakarta. 